\title{
HOW MULTINATIONAL CORPORATIONS USE LOBBYING AND ADVOCACY TO MITIGATE POLITICAL RISKS
}

\author{
Violeta Iftinchi ${ }^{1 *}$, Gheorghe Hurduzeu ${ }^{2}$ \\ ${ }^{1}$ Institute for Doctoral Studies, Faculty of International Business and Economics, Bucharest \\ University of Economic Studies, Bucharest, Romania \\ ${ }^{2}$ Faculty of International Business and Economics, Bucharest University of Economic \\ Studies, Bucharest, Romania \\ violetaiftinchi@gmail.com \\ gheorghe.hurduzeu@rei.ase.ro
}

\begin{abstract}
In their international activities multinational corporations (MNCs) face various risks. Political risk is one of them. Expropriations, transfer and convertibility restrictions, breach of contracts, acts of terrorism, domestic political violence or other adverse regulatory changes and/or negative government action represent forms of political risks. Incorporating political risk in their risk management strategies becomes a necessity for MNCs in their search for profits and new markets. This article presents how MNCs use lobbying and advocacy as means to engage with governments and politicians in the country of origin (home country), in the country where a MNC has operations (host country) or at international level (by creating ties with international organisations) in order to mitigate political risks. The case of Repsol and its investment in Argentina is used to demonstrate the application of such tools. The article presents two limitations that might determine the success or failure of MNCs' lobbying and advocacy activities: governments' unpredictable views towards MNCs and reputational risks. The article has also identified a main difficulty in identifying and examining MNCs way of using lobbying and advocacy to engage with government officials and politicians. This difficulty comes from the informal character of such contacts which makes lobbying and advocacy almost impossible to identify.
\end{abstract}

Keywords: political risk, multinational corporations, lobbying, advocacy, risk management.

JEL classification: F01, F21, F23.

\section{Introduction}

The survey carried out by World Bank on 750 executives of multinational corporations (MNCs) investing in developing countries, and released on 25 October 2017 as part of the Global Investment Competitiveness Report 2017-2018, found that more than three-quarters of MNCs identified some type of political risk in their investment projects in developing countries. A quarter of investors that did experience disruptions cancelled or withdrew their investment (World Bank, 2017).

Molano (2008, p.18) defines political risk as "the broad spectrum of actions in the political and social environment which can influence a transnational actor's property rights, income or market'. Political risks can take the form of expropriation or nationalisation, transfer and convertibility restrictions, breach of contracts, acts of terrorism, domestic political violence (e.g. the hostile actions of national forces, revolutions, civil war, and insurrection) or other adverse regulatory changes and/or negative government action. Although political risks can appear both in developed and developing countries, they are more relevant to MNCs operating in developing countries (Bremmer and Keat, 2009; McKellar, 2010).

\footnotetext{
${ }^{*}$ Corresponding author: Violeta Iftinchi.
} 
Under pressure to gain profits and enter new markets, the number of cases where MNCs withdraw their investment should be limited. According to the report of the Multilateral Investment Guarantee Agency (MIGA) on world investments and political risk in 2013, 44\% of MNCs were using engagement with the government in the host country to mitigate political risks when investing in developing countries (MIGA, 2014). In its 2011 and 2012 World Investments and Political Risk reports, MIGA finds that informal risk mitigation through engagement with key political figures remains the most effective approach used by foreign investors to mitigate expropriation (MIGA, 2011).

Given the nature of political risks, using government relations, lobbying and strategic relationships with politicians are a number of tools available to MNCs to minimise political risks. Cultivating ties with government officials and politicians can provide useful communication channels and insights into the governments' behaviour.

Researchers and practitioners use various terms to describe the tools that MNCs use to liaise with government officials and politicians. Corporate lobbying, advocacy, commercial or business diplomacy, political engagement are only a few terms used to describe governments and politicians intervention in favour of MNCs. How MNCs liaise with government officials and politicians is not formalised in a process and it takes place usually in an informal way which is not visible most of the time to an outsider. Irrespective of the conceptualisation of those terms, this article aims to present the final result of those interventions in favour of MNCs: how engagement with governments and politicians from the host country, home country and international organisations can mitigate political risks. When engaging with governments and politicians, MNCs can involve in lobbying and advocacy activities. Although the line between lobbying and advocacy is often blurred, there are at least two differences between the two activities. In their lobbying activities MNCs can use an intermediary who is representing the interests of the company (Keillor, Wilkinson and Owens, 2005), while direct contacts are used in advocacy. Lobbying is used to achieve short-term, single objectives (Keillor, Boller and Ferrell, 1997), while advocacy involves long-term activities directed at relational goals (Keillor, Pettijohn and Bashaw, 2000; Keillor and Hult, 2004).

MNCs engage in lobbying and advocacy either to maximise their profits (Chao, Kaempfer and Lowenberg, 2003) or to minimise any potential or announced adverse actions against their activities, like nationalisation threats (Keillor, Wilkinson and Owens, 2005).

This article presents how MNCs use lobbying and advocacy as means to engage with governments and politicians in order to mitigate political risks. It examines how MNCs use lobbying and advocacy in their home and host country, and also at international level. The article includes related examples and the case of Repsol and its investment in Argentina is the most relevant given that home, host and international lobbying and advocacy were used. The article will also highlight the limitations of using each of those tools.

\section{Lobbying and advocacy in MNCs' home country}

Tarzi (2010) argues that home governments may support MNCs for a number of reasons like maintaining access to cheap resources and improvement of their balance of payments. MNCs can also extend the economic and political influence of States (Tully, 2012) thus benefitting of a special treatment and support of the home country. Lobbying the home government becomes a good asset for a MNC (Hadjikhani, Lee and Ghauri, 2008).

The home country can influence the business environment faced by its firms abroad (Luo, 2004; Rizopoulos and Sergakis, 2010; Desbordes, 2010). Good relationships between the home and the host country can reduce the exposure of MNCs to political risks and offer them a competitive advantage over their international competitors (Desbordes, 2010).

At the beginning of 2012 when rumours of a possible intervention of the Argentinean government in Repsol's subsidiary in Argentina, YPF, started to escalate on the market, 
Repsol started an intensive lobbying campaign in its own country, Spain. Spain's King Juan Carlos intervened at the end of February 2012 between Repsol and the Argentinean government. After King's Juan Carlos discussion with President Fernández and the visit of Spanish Minister for Industry, José Manuel Soria, in Buenos Aires, Argentina and Spain agreed to form a working group aimed at sorting out the "differences" over YPF. According to the press, the Spanish diplomacy highlighted the strategically important role of Repsol for Spain (Johnson and Webber, 2012).

On 20 March 2012, José Manuel Soria, declared that Spain will support the interests of Repsol in front of the Argentinean government (Algañaraz, 2012). On 12 April 2012, he threatened with consequences to any actions from Argentina regarding Repsol. Spain's government has warned that any "hostile gestures" against Spanish companies doing business abroad would be seen by Madrid as an act of aggression (Romero and Schmall, 2012).

Research also shows that MNCs risk appetite depends also on the support of the home country. This is more evident with Chinese MNCs. In their research into how Chinese firms decide on how to place international investments, Ramasamy, Yeung and Laforet (2012) find that State-controlled Chinese firms are attracted to countries with significant natural resources and risky political environments. The authors argue that this is because Chinese State-owned companies rely heavily on the relationship between the Chinese government and the host country as the basis for their investment decisions. The risk of nationalization and non-repayment of contracts may be reduced if the investment is based on the support of the government of the home country as well as on political affiliations and links between China and other governments in developing countries. This gives Chinese companies an advantage over Western companies that are less interested in entering high-risk markets. O'Neill (2014) arrives at the same conclusion when studying the behaviour of State-owned Chinese companies operating in Kazakhstan.

\section{Lobbying and advocacy in MNCs' host country}

Host countries usually consider MNCs to be beneficial for local economies. From the host government's perspective, corporate operational efficiency accelerates economic development by using national resources more productively than they would otherwise be used, (Tully, 2012). Additionally, it can aid the local economy; moreover, governments may lack the financial resources to invest in large and costly projects. From the corporations' position, positive relationships with the government can help alleviate negative actions.

Personal relationships with well-connected persons, especially government officials, can be a great asset for a company (Bremmer and Keat, 2009). In this case, the host government can turn from a source of political risk into a potential ally for MNCs, especially when the host country's political environment is characterized by a precarious legal system. Keillor, Wilkinson and Owens (2005) find that lobbying in the host country appears to be of great importance when companies face risks such as import restrictions, expropriation, threats to nationalization, pressures to transfer investment, and local requirements on property rights. Moreover, personal contacts with government officials may reduce the MNCs risks from domestic political instability, such as civil war and other violent forms of conflict. Governments typically have more means of collecting information (such as direct access to national classified information) and identifying potential civil conflicts, which MNCs can benefit from. As McKellar (2010) recognizes, information is one of the ways government contacts can help companies. The relationship with various political actors allows MNCs to understand the political environment and behaviour of government officials (Keillor, Boller and Ferrell, 1997; Léonard, 2004) and provide early warnings about policy or government shifts towards foreign investors (McKellar, 2010; Accenture, 2012). For instance, the American company Chevron started an intensive lobbying campaign in 2012 after the new 
government introduced a moratorium on shale gas operations (EPG, 2017). Lack of attention or ignorance of political stakeholders like governments may lead to severe conflicts, and eventually to financial losses (Holtbrügge, Berg and Puck, 2007).

MNCs have to also consider the relationship between the local authorities on the one hand and the central government authorities, on the other hand. In their study on the pressure exerted by the Chinese government on multinational corporations operating in China, Osland and Björkman (1998) recommend MNCs to work closely with local and provincial authorities as well as with central government officials to identify and manage potential differences in political agendas at central and local levels. Especially in large countries, MNCs can be exposed to the political power of the local authorities they need to interact with, which do not necessarily reflect the views of the central government. This is usually the case for foreign investors operating in Russia. In case of conflict with the local authorities, MNCs can put forward their case to the central government which might be more open to the grievances of the MNCs than the local government.

Each MNC's choice of methods to engage with political leaders is specific and depends on the MNC's bargaining power in relation to the host government and the firm's comparison of expected gains between various approaches (Luo, 2004; Barron, 2011). Luo (2004) recommends that MNCs should revise their choice of methods when political conditions and situations change.

Repsol' political risk management strategy included lobbying and engagement with the Argentinean government as a tool to mitigate its political risks in Argentina. According to the press, Repsol YPF had contributed to the 2003 electoral campaigns of both Carlos Menem and Néstor Kirchner with amounts up to USD 1 million (Mercado, 2012). It is important to mention that donations to political parties are not illegal in Argentina. They are requested by the political parties and carried out through foundations. The Argentinean Planning Minister, Julio de Vido, worked closely with Repsol's management (Forero, 2012). Roberto Barrata, the government representative on the YPF's board declared on 2 November 2011 that the Argentinean government was in complete agreement with the activities of the company (Johnson, 2012). Antonio Brufau, Repsol's president, often met with Argentinean top officials in the economic and energy sector (Forero, 2012).

\section{International lobbying and advocacy}

To minimise the risk of expropriation, MNCs can involve influential international parties in their foreign investment activities, including other governments (Hain, 2011). For that reason, Repsol and Spain relied on the support of the European Commission (Moffett and Turner, 2012). It was not the first case when the European Commission was ready to intervene in a conflict involving one European MNC and a foreign government. In April 2006, the EU Commissioner for Trade gave his support to the Finnish company Botnia in the conflict with Uruguay and Argentina (Joutsenvirta and Vaara, 2009). More recent, the European Commission warned the US authorities on their intention to impose duties of $300 \%$ on Bombardier's C Series jets. Though not a European based MNC, the potential measure against the Canadian Bombardier triggered concerns in the UK as the MNC has a plant that is critical to the Northern Ireland's economy. The issue is very sensitive for the UK government which needs to cope with a fragile alliance with the Northern Irish DUP party (Brunsden and Beattie, 2017).

At the beginning of April 2012, Olivier Bailly, spokesman for the European Commission, stated that Argentina should respect the "international engagements on the treatment and the protection of international investments on its territory". Bailly added that Argentina and Spain must forge a solution over YPF that does not "damage the working environment and economic relations between the European Union and Argentina" (Warren, Calatrava and Steinhauser, 2012). 


\section{Limitations}

Using the tools presented in this article as part of political risk management strategy does not necessarily ensure a MNC's success in mitigating political risks. Firstly, governments can easily take action against MNCs despite them having developed good relationships in the past, or MNCs being supported by their home country or other international organization. Secondly, lobbying and advocacy can come with reputational risks which can affect the activity of MNCs.

\subsection{Governments' unpredictable views towards MNCs}

Governments in developing countries would more easily withdraw their support for MNCs than governments in developed countries (Rottig, 2016). Especially in natural-resource-dependent economies, governments are less sensitive to the reputational costs stemming from the deterioration of investors' perception of their business environment (Jensen and Johnston, 2011) and therefore more prone to extreme actions like nationalisations. This was the case of Repsol. The company used all three tools presented in this article to mitigate its political risks in Argentina. However, this did not prevent the nationalization of Repsol's subsidiary in Argentina, YPF, on 16 April 2012.

In spite of the significant support, Spain and the European Commission or the previous good relationship built with the Argentinian officials were not able to stop the nationalisation (Johnson, 2012). On 25 May 2012, the EU's Trade Commissioner Karel De Gucht denounced the aggressive and nationalistic behaviour of Argentina in nationalising Repsol (Doncel, 2012). One drawback in Repsol's strategy was that it was not able to find support from the US which disapproved of the company's operations in Cuba (Oppenheimer, 2012; El País, 2012).

Looking retrospectively, the lobbying campaign seemed the most appropriate option in the circumstances. As the head of government (President, Prime Minister, etc.) is the most likely person to be actively involved with an expropriation (MIGA, 2011), high level lobbying is the most suitable tactic to manage this risk. Moreover, the Kirchners' administration was always very careful with their relationship with Spain, as they saw it as access to the European Union (Van der Kooy, 2012). Also for that reason, the decision to disregard the repetitive warnings of Spain and the European Commission came unexpectedly and against Argentina's own interests.

In this case, the good relations cultivated with the Argentinean government did nothing to help Repsol (Wagner, 2012). Until November 2011, Repsol seemed to have a very good relationship with the government officials. It cannot be claimed that Repsol was a company lacking experience or resources in dealing with governments in high risk countries like Argentina. Repsol's president, Antonio Brufau, negotiated with Castro brothers in Cuba and Hugo Chavez in Argentina (Forero, 2012). It is clear that the political environment for Repsol changed in November 2011 with the discovery of the Vaca Muerta shale gas field. However, it is difficult to detect if Repsol has adjusted its engagement with the country's politicians according to the new political conditions, as scholars and practitioners recommend. If it proceeded with such a change, it was not successful.

\subsection{Reputational risks}

If local or central governments and politicians are involved in corruption or in any other activities that contribute to the proliferation of war crimes, genocide and crimes against humanity, MNCs' reputation can be significantly damaged.

Lobbying and advocacy are perceived as closely linked to the risk of corruption, as shown by Transparency International in its 2012 report on Europe's corruption risks. Very few companies are willing to reveal their contributions to election campaigns or spending on lobbying activities. To address the corruption risk, Transparency International recommends that businesses: 1 . stop the use of donations to political parties, candidates and elected 
officials as a means to gain personal or policy favours or buy access to politicians or civil servants; 2. disclose all political contributions (both domestic and international); 3 . disclose publicly and regularly lobbyists' clients, issue areas, targets, techniques and financial information; 4. ensure corporate reporting by companies includes lobbying efforts, political activities and spending; and lastly, disclose any forms of political engagement, such as funding or support for civil society organisations, scientific research or public relations activities (Transparency International, 2012, p.50).

Tully (2012) highlights that foreign firms should avoid complicity with local or central governments and politicians in providing products, services, financial aid or any other form of support when there is a danger that they will contribute to the proliferation of war crimes, genocide and crimes against humanity. In September 1997, residents of several Myanmar villages filed a complaint against the Oil Company of California, (Unocal) and the parent company, under the provisions of the Alien Tort Claims Act. Unocal was accused of complicity in killing, torturing, using forced labour and destroying property by the military regime in Myanmar while securing the Yadana pipeline in which Unocal was a participant. Many other MNCs found themselves in similar situations.

\section{Conclusions}

Large budgets and reputations give MNCs multiple advantages in international business. Using access to governments and politicians in the home or host country or in international organisations, MNCs can use lobbying and advocacy to mitigate their political risks. Both home and host country have their own interests to support the activity of MNCs at a certain point in time, while international organisations have the power to incorporate individual disputes in a wider context. Our research shows that MNCs will use a combination of those tools and would escalate their efforts when risks increase, starting with the host country and continuing with the home country and international organisations (like it happened in the case of Repsol). Romanian officials have also been the target of MNCs' lobbying and advocacy (the case of Chevron). For European companies, it seems that the institutions of the European Union are the ones which are targeted, and amongst them, the European Commission.

The article also presents two limitations that might determine the success or failure of MNCs' lobbying and advocacy activities. The reaction of governments is sometimes unpredictable and can easily turn against MNCs. Repsol relied heavily on the support of Spain and the European Commission to put pressure on Argentina. Unexpectedly, the Argentinian government proved immune to such warnings, as many other governments in resource rich countries. Reputational risks that come with government officials and politicians' involvement in corruption or any other activities that contributes to the proliferation of war crimes genocide and crimes against humanity can also affect MNCs' international activity, as in the case of Unocal.

The article has identified a main difficulty in identifying and examining MNCs way of using lobby and advocacy to engage with government officials and politicians. This difficulty comes from the informal character of those contacts which makes them almost impossible to identify. Public statements and media can only hint at potential contacts between MNCs and government officials and politicians. Because of the lack of observable data, qualitative research is better used to demonstrate how MNCs use lobby and advocacy to mitigate their political risks, like in the case of Repsol. There is only a limited amount of research available that puts forward quantitative analysis on the effectiveness of lobbying and advocacy in international business. For instance Gertz (2017) uses temporary vacancies in the position of U.S. ambassador in American embassies abroad as a novel indicator to measure access to commercial diplomacy. The conclusions of this article highlight that future directions of research should work on identifying new indicators to commensurate the MNCs 
effectiveness of using lobby and advocacy as a way to engage with government officials and politicians to mitigate their political risks.

\section{References}

Accenture, 2012. Managing Political Risk: Controlling Loss, Finding Opportunity. [pdf] Available

http://www.accenture.com/SiteCollectionDocuments/PDF/Accenture-Managing-Political-Ri sk-Controlling-Loss-Finding-Opportunity.pdf [accessed 3 August 2012].

Algañaraz, J. C., 21 March 2012. Según Fitch, se incrementa el riesgo de una nacionalización. Clarín, p. 8.

Barron, A., 2011. Exploring culture's consequences on international business lobbying. Journal of World Business, 43(3), pp. 320-327.

Bremmer, I. and Keat, P., 2009. The fat tail, New York: Oxford University Press.

Brunsden, J. and Beattie, A., 16 November 2017. EU to help Britain fight proposed US tariffs on Bombardier. Financial Times, p. 2.

Chao, J., Kaempfer, W. H. and Lowenberg, A. D., 2003. A public choice model of the role of multinational firms in international relations. The North American Journal of Economics and Finance, 14(1), pp. 131-144.

Desbordes, R., 2010. Global and Diplomatic political risks and foreign direct investment. Economics \& Politics, 22(1), pp. 92-125.

Doncel, L., 25 May 2012. Argentina actúa agresivamente. El País [online]. Available at: http://economia.elpais.com/economia/2012/05/25/actualidad/1337972703 612027.html [accessed 2 February 2013].

El País, 31 May 2012. Repsol stops drilling for oil off Cuba [online] Available at: http://elpais.com/elpais/2012/05/31/inenglish/1338473455 236104.html [accessed 2 February 2013].

EPG, 17 August 2017. No shale gas, after all. Implications of Chevron's exit from Romania [online]

Available

at:

https://www.enpg.ro/no-shale-gas-after-all-implications-of-chevrons-exit-from-romania/ [accessed 7 May 2018].

Forero, J., 26 April 2012. Behind Argentine Seizure, a complex tale. The Washington Post, p. 8.

Gertz, G., 2017. Commercial diplomacy and political risk. Global Economy \& Development working paper 106. [online] Available http://www.dailymail.co.uk/wires/afp/article-5249135/Macron-visits-Forbidden-City-China-d eals-Xi-talks.html [accessed 8 January 2018].

Hadjikhani, A., Lee, J-W. and Ghauri, P.N., 2008. Network view of MNCs socio-political behaviour. Journal of Business Research, 61(9), pp. 912-924.

Hain, S., 2011. Risk perception and risk management in the Middle East market: theory and practice of multinational enterprises in Saudi Arabia. Journal of Risk Research, 14(7), pp. 819-835.

Holtbrügge, D., Berg, N. and Puck, J. F., 2007. To bribe or to convince? Political stakeholders and political activities in German multinational corporations. International Business Review, 16(1), pp. 47-67.

Jensen, N. M. and Johnston, N. P., 2011. Political risk, reputation, and the resource curse. Comparative Political Studies, 44, pp. 662-688.

Johnson, M., 12 June 2012. Repsol's travails remind business of risks. Financial Times: UK edition, p. 4.

Johnson, M. and Webber, J., 2 March 2012. Spain confident YPF dispute can be resolved. Financial Times. [online] Available at: 
http://www.ft.com/intl/cms/s/0/d19d9082-63cd-11e1-8762-00144feabdc0.html\#axzz2LBDFI zIC [accessed 2 February 2013].

Joutsenvirta, M. and Vaara, E., 2009. Discursive (de)legitimation of a contested Finnish greenfield investment project in Latin America. Scandinavian Journal of Management, 25(1), pp. 85-96.

Keillor, B. D., Boller, G. W. and Ferrell, O. C., 1997. Firm-Level Political Behavior in the Global Marketplace. Journal of Business Research, 40(2), pp. 113-126.

Keillor, B. D., Pettijohn, C. E. and Bashaw, R. E., 2000. Political activities in the global industrial marketplace. Industrial Marketing Management, 29(6), pp. 613-622.

Keillor, B. D., Wilkinson, T. J. and Owens, D., 2005. Threats to International Operations: Dealing with Political Risk at the Firm Level. Journal of Business Research, 58(5), pp. 629-635.

Keillor, B.D. and Hult, T.M. 2004. Predictors of Firm-Level Political Behavior in the Global Business Environment. International Business Review, 13(3), pp. 309-329.

Léonard, J. M. M., 2004. Why Firms Fail to Manage Political Risk: Explaining and Correcting Organisational Failures. In Wilkin, S., 2004. Country and Political Risk. Practical insights for global finance, Risk Books. pp. 271-300.

Luo, Y., 2004. A coopetition perspective of MNC-host government relations. Journal of International Management, 10(4), pp. 431-451.

McKellar, R., 2010. A short guide to political risk, Farnham: Gower.

Mercado, F., 23 June 2012. YPF hizo donaciones electorales a Néstor Kirchner. El País. [online] Available at:

http://economia.elpais.com/economia/2012/06/23/actualidad/1340461256 905656.html [accessed 2 February 2013].

MIGA, 2014. World Investment and Political Risk Report. [pdf] Available at: https://www.miga.org/documents/WIPR13.pdf [accessed 23 March 2016].

MIGA, 2011. World Investment and Political Risk Report. [pdf] Available at: http://www.miga.org/documents/WIPR11.pdf [accessed 23 March 2016].

Moffett, M. and Turner, T., 17 April 2012. Argentina to Seize Control of Oil Firm. The Wall

Street Journal Europe. [online] Available at:

http://online.wsj.com/article/SB10001424052702304432704577347801235907294.html

[accessed 2 February 2013].

Molano, W., 2008. Approaches to Political Risk Analysis, in Howell, L. D., 2008. Political Risk Assessment: Concept, Method and Management, 2nd ed., East Syracuse, NY: PRS Group. pp.17-35.

O`Neill, D. C., 2014. Risky Business: The Political Economy of Chinese Investment in Kazakhstan. Journal of Eurasian Studies, 5(2), pp. 145-156.

Oppenheimer, A., 22 May 2012. ¿Expulsará el G-20 a la Argentina? La Nación, p. 17.

Osland, G. and Björkman, I., 1998. MNC - Host Government Interaction: Government Pressures on MNCs in China. European Management Journal, 16(1), pp. 91-99.

Ramasamy, B., Yeung, M. and Laforet, S., 2012. China's outward foreign direct investment: Location choice and firm ownership. Journal of World Business, 47(1), pp. 17-25.

Rizopoulos, Y. A. and Sergakis, D. E., 2010. MNEs and policy networks: Institutional embeddedness and strategic choice. Journal of World Business, 45(3), pp. 250-256.

Romero, S. and Schmall, E., 12 April 2012. Argentina Has Oil Firm in Its Sights. The New York Times. [online] Available at:

http://www.nytimes.com/2012/04/13/business/global/argentina-has-oil-firm-in-its-sights.htm ! [accessed 2 February 2013].

Rottig, D., 2016. Institutions and emerging markets: effects and implications for multinational corporations. International Journal of Emerging Markets, 11(1), pp. 2-17.

Transparency International, 2012. Money, Politics, Power: Corruption Risks in Europe. [online] Available at: 
http://www.transparency.org/whatwedo/pub/money politics and power corruption risks i n europe [accessed on 6 June 2012].

Tully, S., 2012. International Corporate Legal Responsibility, Wolters Kluwer Law \& Business, The Netherlands.

Van der Kooy, E., 21 March 2012. La ofensiva contra YPF, con riesgo de entrar en una zona sin control. Clarín, p. 9.

Wagner, D., 2012. Managing Country Risk: A Practitioner's Guide to Effective Cross-Border Risk Analysis, Taylor \& Francis Group.

Warren, M., Calatrava, A. and Steinhauser, G., 13 April 2012. Spain summons Argentine ambassador in oil dispute. The Guardian. [online] Available at:

http://www.guardian.co.uk/world/feedarticle/10193364 [accessed 2 February 2013].

World Bank, 2017. Global investment competitiveness report 2017-2018 : foreign investor perspectives and policy implications. [pdf]. Available at: http://documents. worldbank.org/curated/en/169531510741671962/pdf/121404-PUB-PUBLI C-PUBDATE-10-25-2017.pdf, [accessed 9 January 2018].

\section{Bio-note}

Violeta Iftinchi is a PhD student at the Institute for Doctoral Studies, International Business and Economics PhD Programme, Bucharest University of Economic Studies. The current paper is part of her research for the Ph.D. thesis "Political Risk Management in Transnational Corporations". The views expressed in this article are those of the author. Gheorghe Hurduzeu, Ph.D., is professor and Dean at the Faculty of International Business and Economics, Bucharest University of Economic Studies. 